\title{
PENGARUH PENGETAHUAN, PERSEPSI DAN PREFERENSI RISIKO MASYARAKAT DI KABUPATEN MAJENE TERHADAP MINAT BERINVESTASI DI PASAR MODAL
}

\author{
Zulfadhli Lutfi A. Lopa,S.E.Ak.,MM ${ }^{1}$ \\ Sri Astuty Ratnasari Manggu,S.E.,M.Ak ${ }^{2}$ \\ ${ }^{1,2}$ Program Studi Akuntansi Fakultas Ekonomi Universitas Sulawesi Barat \\ email: zoelfa91@gmail.com \\ email: sriastutyrm@gmail.com
}

\begin{abstract}
ABSTRAK
Penelitian ini bertujuan untuk mengetahui pengaruh pengetahuan, persepsi dan preferensi resiko masyarakat di kabupaten Majene terhadap minat masyarakat untuk berinvestasi di pasar modal. Metode pengumpulan data dilakukan dengan penarikan sampel dari populasi dengan sistem cluster : yaitu mahasiswa, pegawai swasta/PNS, pengusaha/wiraswasta, professional dan masyarakat umum yang ada di Kabupaten Majene. Teknik pengumpulan datanya melalui kuisioner, sedangkan analisis data dengan analisis deskriptif dan analisis regresi linier berganda. Hasil penelitian menunjukkan bahwa sebagian besar responden secara umum telah mengetahui tentang investasi sahamn dan pasar modal. Akan tetapi hanya sebagian kecil yang kemudian telah melakukan investasi di pasar modal tersebut. Dari sisi persepsi masyarakat, pada umumnya masih banyak persepsi yang tidak tepat terkait pasar modal dan investasi saham yang berkembang di masyarakat. Dari sisi preferensi risiko, seabagian besar masyarakat di kabupaten Majene tergolong kategori investor yang risk averse atau menghindari risiko. Berdasarakan analisis regresi linier berganda, diperoleh hasil yaitu secara bersama-sama, ketiga variabel: pengetahuan, persepsi dan preferensi risiko berpengaruh terhadap minat masyarakat untuk berinvestasi di pasar modal. Akan tetapi secara parsial, hanya variabel pengetahuan dan preferensi risiko yang mempengaruhi minat masyarakat untuk berinvestasi di pasar modal. Hal ini menunjukkan bahwa stigma negatif terkait persepsi masyarakat akan investasi saham tidak mempengaruhi minat masyarakat dalam berinvestasi. Akan tetapi tingkat pengetahuan dan preferensi risiko lah yang lebih mempengaruhi. Hal ini juga secara tidak langsung menunjukkan bahwa masyarakat masih sangat kekurangan informasi yang luas dan mendalam tentang investasi di pasar modal. Begitu juga pemahaman masyarakat akan risiko dalam berinvestasi.
\end{abstract}

Kata Kunci: Pengetahuan, Persepsi Masyarakat, Preferensi Risiko, Investasi, Pasar Modal.

PENDAHULUAN

Investasi menjadi salah satu hal yang kini menjadi kebutuhan bagi masyarakat di Indonesia. $\mathrm{Hal}$ ini dikarenakan adanya keinginan masyarakat untuk memperoleh keuntungan dari hasil investasi yang diperolehnya di masa yang akan 
datang. Sebagaimana yang diungkapkan oleh Sarah (2014) yang menyebutkan bahwa investasi sebagai tidak melakukan kegiatan konsumsi yang berlebihan pada saat ini untuk mendapatkan keuntungan yang lebih besar di masa mendatang.

Nasution dan Huda (2008) menyebutkan bahwa terdapat dua jenis investasi yaitu, investasi pada financial asset dan investasi pada real asset. Investasi pada financial asset yaitu investasi yang dilakukan di pasar uang diantaranya yaitu sertifikat deposito, commercial paper, dan surat berharga pasar uang lainnya. Investasi pada real asset yaitu pembelian asset produktif, seperti properti, perkebunan, pendirian pabrik dan lain-lain). E-paper bisnis Indonesia (2016) mencatat bahwa investasi pada properti, baik tanah maupun bangunan atau di bidang komoditas seperti logam mulia dan emas batangan merupakan jenis investasi yang paling banyak diminati oleh masyarakat.

Selain kedua jenis investasi tersebut, terdapat pula jenis investasi lainnya yaitu investasi sekuritas yang terdapat di pasar modal. Apabila dibandingkan dengan investasi di pasar uang, investasi di pasar modal justru masih kurang diminati oleh masyarakat. Berdasarkan data yang diperoleh dari pers release KSEI (PT Kustodian Sentral Efek Indonesia), yang merupakan salah satu anak perusahaan dari PT Bursa Efek Indonesia yang mengelola pasar modal pada tanggal 10 Agustus 2016, dipaparkan bahwa total aset saham yang tercatat masih didominasi oleh investor asing dengan persentase kepemilikan sebesar 64\%. Secara nilai, tercatat kepemilikan investor asing naik sebesar 9\%, sedangkan nilai kepemilikan saham investor lokal meningkat $8 \%$ dari tahun sebelumnya. (www.ksei.co.id, diakses maret 2017)
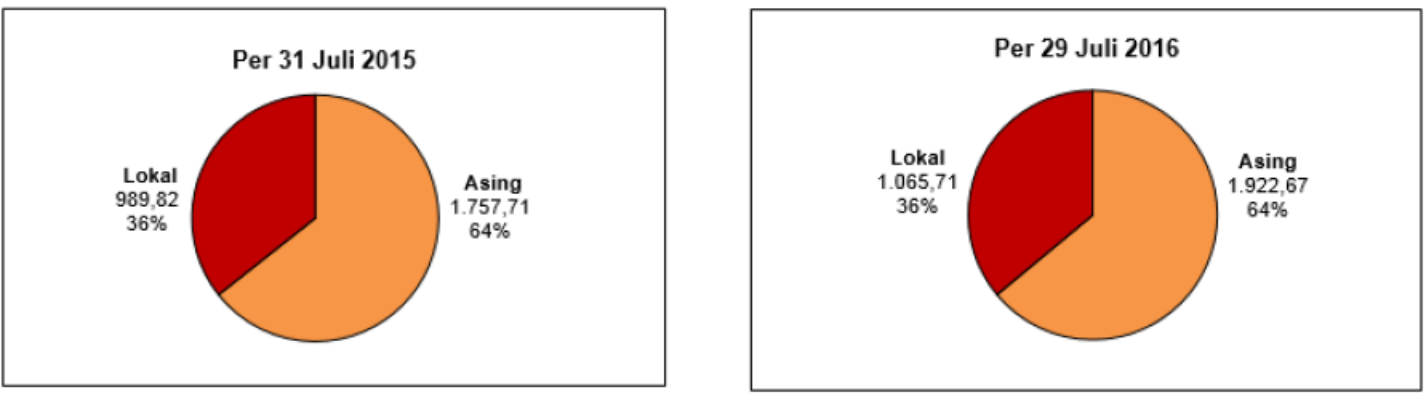

\section{Gambar 1 Komposisi Kepemilikan Saham}

Berdasarkan gambar di atas dapat kita lihat bahwa investor asing masih menguasai pasar modal Indonesia dibandingkan dengan para investor lokal dari Indonesia. Hal ini menunjukkan fakta bahwa masayarakat pada umumnya masih sangat kurang minatnya untuk berinvestasi di pasar modal kita sendiri.
Salah satu hal yang menjadi alasan kurangnya minat yaitu kurangnya pengetahuan tentang pasar modal itu sendiri. Oleh karena itu, saat ini Bursa Efek Indonesia memperkenalkan program "Yuk Nabung Saham" sebagai salah satu bentuk edukasi dan sosialisasi kepada masyarakat agar mau berinvestasi di pasar modal. Hal ini bertujuan untuk 
meningkatkan kepemilikan saham dalam negeri sehingga sektor-sektor vital Indonesia mayoritas akan dimiliki oleh masyarakatnya sendiri bukan sebaliknya malah dimiliki oleh pihak asing.

Selain pengetahuan tentang investasi di pasar modal, masih banyak juga berkembang persepsi yang salah dan cenderung negatif tentang pasar modal yang kemudian menjadikan masyarakat semakin takut dan justru menghindari untuk berinvestasi di pasar modal. Seperti adanya stigma negative yang menganggap bahwa berinvestasi di pasar modal dianggap seperti orang berjudi khususnya bagi kalangan masyarakat muslim. Akan tetapi bahkan saat ini pasar modal juga sudah menyediakan wadah bagi para investor yang ingin berinvestasi di pasar modal tapi khawatir dengan jenis emiten atau perusahaan yang tidak sesuai dengan sistem syariah Islam, yakini dengan adanya saat ini pasar modal syariah.

Selain kedua faktor tersebut, peneliti juga memasukkan preferensi risiko sebagai hal yang juga diperlukan orang untuk berinvestasi yang kemudian dapat mempengaruhi minat dalam berinvestasi. Hal ini sejalan dengan penelitian yang dilakukan oleh Alleyne dan Broom (2011) mengatakan bahwa minat berinvestasi seorang wanita dipengaruhi oleh sikap, kontrol dan preferensi risiko. Preferensi investor dalam hal investasi tersebut, erat kaitannya dengan penilaian terhadap return dan risiko investasi. Setiap investor mampu menanggung risiko yang berbeda-beda, tetapi tentu mereka mengharapkan return yang sesuai.
Kabupaten Majene merupakan salah satu dari 6 kabupaten dalam wilayah Propinsi Sulawesi Barat yang terletak di pesisir pantai barat Propinsi Sulawesi Barat memanjang dari Selatan ke Utara. Luas wilayah Kabupaten Majene adalah 947,84 km2 atau 5,6\% dari luas Propinsi Sulawesi Barat yang secara administratif berbatasan dengan wilayah-wilayah kabupaten Mamuju di sebelah Utara, kabupaten Polewali Mandar dan kabupaten Mamasa di sebelah Timur, Teluk Mandar di sebelah Selatan dan selat Makassar di sebelah Barat. Sejak dipilihnya kabupaten Majene sebagai kota pendidikan, giat perekonomian mulai berkembang dengan pesat. Sehingga menarik untuk meneliti terkait minat investasi masyarakat khususnya investasi di pasar modal.

\section{TINJAUAN PUSTAKA Investasi}

Menurut Ikatan Akuntansi Indonesia (IAI) dalam PSAK Nomor 13 (2008), investasi adalah suatu aktiva yang digunakan oleh perusahaan untuk menumbuhkan kekayaan (accretion of wealth) melalui distribusi hasil investasi (seperti bunga, royalti, dividen dan uang sewa), untuk apresiasi nilai investasi, atau untuk manfaat lain bagi perusahaan yang berinvestasi seperti manfaat yang diperoleh melalui hubungan perdagangan. Sedangkan Kasmir dan Jakfar (2012) menguraikan bahwa investasi dapat diartikan sebagai penanaman modal dalam suatu kegiatan yang memiliki jangka waktu relatif panjang dalam berbagai bidang usaha. Penanaman modal yang ditanamkan dalam arti sempit berupa proyek tertentu baik bersifat fisik atau pun non fisik, seperti proyek pendirian 
pabrik, jalan, jembatan, pembangunan gedung dan proyek penelitian, dan pengembangan.

$$
\text { Menurut Fahmi (2009:2), }
$$
investasi merupakan bentuk pengelolaan dana guna memberikan keuntungan dengan cara menempatkan dana pada alokasi yang diperkirakan akan memberikan tambahan keuntungan. Menurut Gumanti (2011:3), investasi adalah melakukan pengorbanan pada hari ini untuk memperoleh manfaat lebih baik di waktu yang akan datang. Dari beberapa teori di atas dapat disimpulkan bahwa investasi adalah suatu bentuk cara penanaman modal dengan memiliki aktiva sebagai modal yang dikelola dalam jangka waktu yang panjang dimana hasilnya akan memberi keuntungan di masa yang akan datang.

\section{Pasar Modal}

Husnan (2008) mengemukakan bahwa pasar modal adalah pasar untuk berbagai instrumen keuangan (sekuritas) jangka panjang yang dapat diperjualbelikan, baik dalam bentuk hutang maupun modal sendiri, baik yang diterbitkan oleh pemerintah, public authorities, maupun perusahaan swasta.

Tujuan pasar modal adalah mempercepat proses ikut sertanya masyarakat dalam kepemilikan saham perusahaan swasta menuju pemerataan pendapatan masyarakat, serta menggairahkan partisipasi masyarakat dalam pergerakan dana dan penggunaannya secara produktif untuk pembiayaan pembangunan nasional (Usman, dkk, 1997). Di dalam perekonomian, pasar modal menjalankan fungsi ekonomi yaitu menyediakan fasilitas untuk memindahkan dana dari pihak yang memiliki dana berlebih (surplus fund) kepada pihak yang memerlukan dana (defecit fund). Selain itu, pasar modal juga menjalankan fungsi keuangan yaitu menyediakan sarana bagi pihak yang memerlukan dana dan pihak yang kelebihan dana tanpa harus terlibat langsung dalam kepemilikan aktual riil yang diperlukan untuk berinvestasi.

\section{Jenis Investasi di Pasar Modal}

Pasar modal adalah suatu bentuk pasar dimana instrumen keuangan yang diperdagangkan dapat diperjual belikan, baik dalam bentuk utang maupun modal, baik yang diterbitkan pemerintah, otoritas publik maupun perusahaan swasta. Berbagai instrument yang diperdagangkan, yaitu

\section{1) Saham}

Surat-surat berharga yang diterbitkan oleh perusahaan koorporasi atau Badan Usaha Milik Negara (BUMN), dimana surat berharga tersebut menunjukan kepemilikan dari pemilik perusahaan tersebut. Saham dapat didefinisikan sebagai tanda penyertaan modal seseorang atau suatu badan usaha dalam perusahaan atau perseroan terbatas. Menurut Husnan (2009:29), "saham merupakan secarik kertas yang menunjukan hak pemodal (yaitu pihak yang memiliki kertas tersebut) untuk memperoleh bagian dari prospek atau kekayaan organisasi yang menerbitkan". Wujud saham adalah selembar kertas yang menerangkan bahwa pemilik kertas tersebut adalah pemilik perusahaan yang menerbitkan surat berharga tersebut dan porsi kepemilikan 
ditentukan oleh seberapa besar penyertaan yang ditanamkan dalam perusahaan tersebut (Darmadji , 2012:5).

\section{2) Obligasi}

Menurut Bursa Efek Indonesia, "obligasi (bond) merupakan sertifikat bukti utang dan dikeluarkan oleh suatu perseroan terbatas atau institusi tertentu baik pemerintah maupun lembaga lainnya dengan tujuan mendapatkan modal. Perusahaan membayar bunga atas obligasi tersebut pada tanggal-tanggal yang telah ditentukan secara periodik, dan pada akhirnya menebus nilai utang tersebut pada saat jatuh tempo dengan mengembalikan jumlah pokok pinjaman ditambah bunga yang terutang. Dengan demikian obligasi dapat dikatakan sebagai salah satu instrument pasar modal yang memberikan pendapatan tetap (fixedincome securities) bagi pemegang obligasi". Obligasi adalah dokumen bermaterai yang menyatakan bahwa penerbitnya akan membayar kembali utang pokoknya pada waktu tertentu, dan secara berkala akan membayar kupon kepada pemegang obligasi. Umumnya, obligasi diikat dengan suatu jaminan yang dapat dijual untuk melunasi klaim jika emiten gagal membayar kupon dan pokok pada saat jatuh tempo (Bank Indonesia, 2013).

\section{3) Saham Preferen}

Gabungan antara obligasi dan saham biasa yang memiliki karakteristik seperti obligasi dan karakteristik saham biasa. Karakteristik obligasi misalnya saham preferen memberikan hasil yang tetap seperti bunga obligasi. Biasanya saham preferen memberikan pilihan tertentu atas hak pembagian dividen dengan didahulukannya penerimaan dividen sebelum pembagian dividen kepada pemegang saham biasa. Keuntungan dalam berinvestasi saham preferen yaitu memberikan keuntungan yang lebih pasti, bahkan ada kemungkinan keuntungan tersebut lebih besar dari suku bunga deposito apabila perusahaan dapat menghasilkan laba yang besar, dan pemegang saham preferen memiliki keistimewaan mendapatkan dividen yang dapat disesuaikan dengan suku bunga.

\section{4) Reksa Dana}

Menurut Undang-Undang Pasar Modal No. 8 Tahun 1995, reksa dana adalah wadah yang dipergunakan untuk menghimpun dana dari masyarakat pemodal untuk selanjutnya diinvestasikan dalam portfolio efek oleh menejr investasi yang telah mendapat izin dari Bapepam. Reksa dana berasal dari kata "Reksa" yang berarti jaga atau pelihara dan kata "Dana" berarti uang. Sehingga reksa dana (mutual fund) adalah salah satu investasi dimana investor secara bersama-sama melakukan investasi dalam suatu himpunan dana untuk diinvestasikan dalam berbagai bentuk investasi seperti saham, obligasi ataupun melalui tabungan atau sertifikat deposito di bankbank. Dengan demikian reksa dana adalah diversifikasi dalam portfolio yang dikelola oleh manajer investasi 
di perushaaan reksa dana (Sitompul, 2002:2).

\section{Pengetahuan}

Pengetahuan menurut Engel, Blackwell, dan Miniard yang di kutip oleh Ujang Sumarwan (2003), pengetahuan konsumen adalah semua informasi yang dimiliki konsumen mengenai berbagi macam produk dan jasa, seperti pengetahuan lainnya yang terkait dengan produk dan jasa tersebut dan informasi yang berhubungan dengan fungsinya sebagai konsumen. Pengetahuan akan mempengaruhi keputusan pembelian, ketika konsumen memiliki pengetahuan yang lebih banyak, maka ia akan lebih baik dalam mengambil keputusan, ia akan lebih efisien dan lebih tepat dalam mengelola informasi. Selanjutnya, Engel, Blackwell, dan Miniard yang di kutip oleh Ujang Sumarwan (2003:120123) membagi pengetahuan konsumen kedalam tiga macam yaitu:

1) Pengetahuan produk adalah kumpulan berbagai informasi mengenai produk. Pengetahuan produk terdiri atas pengetahuan tentang atribut produk, pengetahuan tentang manfaat produk, serta pengetahuan tentang kepuasan yang diberikan produk bagi konsumen.

2) Pengetahuan pembelian adalah pengetahuan yang meliputi berbagai informasi yang diproses oleh konsumen untuk memperoleh suatu produk. Dengan adanya pengetahuan pembelian ini konsumen akan menentukan di mana ia akan membeli produk tersebut dan kapan akan membelinya.

3) Pengetahuan pemakaian adalah mencakup informasi yang tersedia di dalam ingatan konsumen mengenai bagaimana suatu produk dapat digunakan dan apa yang diperlukan untuk menggunakan produk tersebut.

\section{Persepsi}

Sutisna (2010) menyatakan bahwa persepsi adalah proses bagaimana stimulus-stimulus yang mempengaruhi tanggapan-tanggapan itu diseleksi dan diinterpretasikan, persepsi setiap orang terhadap suatu objek itu berbeda-beda oleh karena itu persepsi mempunyai sifat subyektif. Stimulus adalah setiap bentuk fisik atau komunikasi verbal yang dapat mempengaruhi tanggapan individu. Salah satu stimulus yang penting yang dapat mempengaruhi perilaku konsumen adalah lingkungan (sosial dan budaya) karena persepsi setiap orang terhadap suatu objek akan berbeda-bada oleh karena itu persepsi mempunyai sifat subjektif. Persepsi seorang konsumen akan berbagai stimulus yang diterimanya di pengaruhi oleh karakteristik yang dimilikinya.

Sementara itu, menurut Nevita dan Arifin dalam Jurnal Nusantara of Research (Vol.02,2015:151) menyatakan bahwa dalam kehidupan sehari-hari persepsi lebih diidentifikasikan sebagai pandangan, yang artinya bagaimana pandangan seseorang terhadap objek atau kejadian pada saat tertentu. Hasil pengamatan tersebut akan diproses secara sadar sehingga individu kemudian dapat memberi arti kepada objek yang diamatinya tersebut.

Menurut Philip Kotler (2009), Persepsi (perception) adalah proses dimana kita memilih, mengatur, dan menerjemahkan masukan informasi 
untuk menciptakan gambaran dunia yang berarti. Point utamanya adalah bahwa persepsi tidak hanya tergantung pada rangsangan fisik, tetapi juga pada hubungan rangsangan terhadap bidang yang mengelilinginya dan kondisi dalam setiap diri kita.

$$
\text { Dari pernyataan-peryataan }
$$

diatas dapat disimpulkan bahwa persepsi adalah suatu proses individu dalam mengenali suatu objek terhadap rangsangan yang diterimanya melalui alat indranya sehingga individu dapat menyimpulkan dan manafsirkan rangasangan yang ia terima.

Sutisna (2010) menyatakan beberapa karakteristik konsumen yang mempengaruhi persepsi adalah sebagai berikut :

1) Membedakan stimulus yaitu bagaimana konsumen bias membedakan antara dua stimuli atau lebih, apakah konsumen merasakan perbedaan antara kedua produk tersebut.

2) Persepsi bawah sadar yaitu kemampuan konsumen memberikan tanggapan terhadap stimulus yang berada dibawah kesadaran atau berada dibawah ambang batas kesadarannya.

3) Tingkat adaptasi adalah ketika konsumen sudah merasa terbiasa dan kemudian tidak lagi mampu memperhatikan stimulus yang berulang-ulang.

4) Seleksi perseptual seperti telah dijelaskan sebelumnya bahwa persepsi merupakan bagian dari evaluasi proses seleksi dan interpretasi terhadap stimulus. Proses persepsi yang pertama adalah seleksi perseptual. Seleksi perseptual terjadi ketika konsumen menangkap dan memilih stimulus berdasarkan pada psikologikal set yang dimiliki. Psikologikal set yaitu berbagai informasi yang ada dalam memory konsumen. Sebelum seleksi persepsi terjadi, terlebih dulu stimulus harus mendapatkan perhatian dari konsumen.

\section{Preferensi Risiko}

\begin{tabular}{lcr}
\multicolumn{1}{c}{ Dalam } & Kamus Besar & Bahasa \\
Indonesia, disebutkan & bahwa \\
preferensi adalah hak (untuk) \\
didahulukan dan diutamakan,
\end{tabular}
diprioritaskan, pilihan kecenderungan atau kesukaan dalam menggunakan atau memanfaatkan suatu barang atau jasa (http://kbbi.web.id, diakses maret 2017). Preferensi Konsumen adalah nilai-nilai pelanggan yang diperoleh dalam menentukan sebuah pilihan. Preferensi konsumen adalah Penilaian keinginan terbaik dari konsumen, preferensi konsumen menentukan pilihan konsumen jika konsumen dihadapkan padabanyak ragam pilihan produk yang sejenis.

(Http://www.ac.id-PreferensiKonsumen, diakses maret 2017).

Dari pernyataan-pernyataan diatas dapat disimpulkan bahwa preferensi adalah kecenderungan seseorang dalam memilih suatu produk yang didasarkan atas keinginan, kepentingan, dan seleranya. Dimana dalam hal ini seorang konsumen diharapkan mampu membedakan setiap produk yang akan dihadapinya, serta membuat daftra preferensinya (rank preference) atas seluruh produk tersebut. Preferensi konsumen bersifat subyektif, dimana preferensi antara konsumen satu dengan yang lainnya tidaklah sama. Ketidaksamaan ini disebabkan oleh perbedaan 
kepentingan dikarenakan banyak faktor.

\section{Minat}

Minat dalam kamus besar bahasa Indonesia diartikan sebagai kecenderungan hati yang tinggi terhadap sesuatu gairah, keinginan (Anton M. Moeliono, 1999:225). Sementara itu menurut Menurut Stiggins (1994) minat adalah salah satu dimensi dalam aspek afektif yang memiliki peran besar dalam kehidupan seseorang. Aspek afektif merupakan aspek yang mengidentifikasi dimensidimensi perasaan dalam kesadaran emosi, disposisi, serta kehendak yang berpengaruh pada pikiran dan tindakan seseorang. Dimensi afektif ini mencakup tiga hal, yaitu:

a) berhubungan dengan perasaan mengenai obyek berbeda;

b) perasaan-perasaan tersebut memiliki arah yang dimulai dari titik netral ke titik yang berlawanan, tidak positif dan tidak negatif;

c) berbagai perasaan yang memiliki intensitas berbeda, dari lemah, sedang,hingga kuat.

Aiken (1994) menyatakan minat sebagai kesukaan terhadap suatu kegiatan, lebih dari kegiatan lainnya. Artinya, minat berhubungan dengan nilai-nilai yang membuat seseorang memiliki pilihan dalam hidupnya. Sedangkan, menurut Salim dan Salim (1996) minat merupakan kecenderungan hati yang tinggi terhadap suatu gairah dan keinginan. Berdasarkan ketiga definisi tersebut, maka dapat disimpulkan bahwa minat adalah salah satu dimensi dalam aspekbafektif yang menyebabkan seseorang memiliki kesukaan terhadap suatu kegiatan, lebih dari kegiatan lainnya, dengan intensitas berbeda, dari lemah, sedang, hingga kuat.

\section{METODE PENELITIAN Populasi}

Populasi penelitian ini meliputi masyarakat di kota Majene khususnya di kecamatan Banggae. Adapun jumlah penduduk di Kabupaten Majene khusunya Kecamatan Banggae berdasarkan data dari Badan Pusat Statistik Kabupaten Majene adalah berjumlah $\quad 40.646 \quad$ jiwa (https://majenekab.bps.go.id). Sampel

Menurut Sugiyono (2008), sampel adalah bagian dari jumlah dan karakteristik yang dimiliki oleh populasi tersebut. Bila populasi besar, dan peneliti tidak mungkin mempelajari semua yang ada pada populasi, maka peneliti dapat menggunakan sampel yang diambil dari populasi itu. Apa yang dipelajari dari sampel itu, kesimpulannya akan dapat diberlakukan untuk populasi.

Berkenaan dengan penentuan jumlah responden yang akan dijadikan sampel untuk mewakili seluruh masyarakat Kabupaten Majene khususnya Kabupaten Banggae, peneliti menentukan jumlah sampel yang diambil adalah sebanyak 100 responden. Sampel penelitian tersebut akan dibagi menjadi lima cluster : kalangan pelajar/mahasiswa (20 responden), kalangan professional (guru,dosen dan profesi lainnya, 20 responden), kalangan pekerja/karyawan pemerintah maupun swasta (20 responden), kalangan pedagang/pengusaha (20 responden), serta kalangan masyarakat umum lainnya (20 responden). 


\section{Variabel dan Pengukuran}

Dalam penelitian ini ada 2 (dua) variabel yang menjadi variabel yang akan diukur yaitu: pengetahua, persepsi, preferensi risiko dan minat. Variabel pertama yang kemudian disebut variabel bebas (independent) yaitu pengetahuan (X1), persepsi (X2), preferensi risiko (X3) dan variable kedua yang kemudian disebut variabel terikat (dependant) yaitu minat (Y). Kedua variabel tersebut akan diukur dan dikumpulkan dengan menggunakan kuisioner.

\section{Metode Analisis Data}

Penelitian ini menganalisis data dengan menggunakan analisis deskriptif kuantitatif. Metode deskriptif digunakan untuk memberikan gambaran tentang faktor-faktor yang mempengaruhi minat masyarakat di Kabupaten Majene dalam berinvestasi di pasar modal dalam kaitannya dengan variabel yang telah ditentukan yaitu: pengetahuan, persepsi dan preferensi risiko. Sementara itu pada metode kuantitatif, penelitian ini menggunakan analisis regresi linier berganda untuk mengetahui pengaruh antara pengetahuan, persepsi dan preferensi risiko (variabel independent) dengan minat (dependent). Adapun rumus model linier yang digunakan digunakan dalam menghitung dugaan regresi mengikuti formula berikut :

$$
\hat{Y}=a+b 1 X 1+b 2 \times 2+b 3 \times 3
$$
dimana :

$\hat{\gamma}=$ Nilai estimasi variabel dependent (Minat)

$X 1=$ Variabel independent (Pengetahuan)

$X 2=$ Variabel independent (Persepsi)

$X 3=$ Variabel independent (Preferensi Risiko)

a = intercept (konstanta)

b1 $=$ Koefisien regresi variabel $X 1$

\section{HASIL DAN PEMBAHASAN}

\section{Karakteristik Responden}

Data dalam penelitian ini diperoleh dengan cara menyebarkan kuesioner kepada 125 orang responden yang berada di Wilayah Kabupaten Polewali khusunya di Kecamatan Wonomulyo dan Kota Polewali. Adapun hasil pengembalian kuisioner berdasarkan cluster sampel sebagai berikut:

Tabel 1 Pengembalian Kuesioner

\begin{tabular}{|c|l|c|c|c|}
\hline \multirow{2}{*}{ No } & \multirow{2}{*}{ Keterangan } & \multicolumn{3}{c|}{ Jumlah } \\
\cline { 3 - 5 } & & Sebar & Kembali & $\begin{array}{c}\text { Tambahan/kekurangan } \\
\text { sesuai cluster }\end{array}$ \\
\hline 1 & Mahasiswa & 20 & 20 & 0 \\
\hline 2 & PNS/Peg.Swasta & 20 & 24 & 4 \\
\hline 3 & Pengusaha/Wiraswasta & 20 & 21 & 1 \\
\hline 4 & Profesional & 20 & 20 & 0 \\
\hline 5 & Masyarakat umum & 20 & 15 & 5 \\
\hline & Total & $\mathbf{1 0 0}$ & $\mathbf{1 0 0}$ & \\
\hline & & \multicolumn{3}{c|}{ Responden Rate $=(\mathbf{1 0 0 / 1 0 0 )} \times \mathbf{1 0 0}=\mathbf{1 0 0 \%}$} \\
\hline
\end{tabular}


Berdasarkan hasil survei dengan menggunakan kuesioner, karakteristik responden yang menjadi sampel dalam penelitian ini dibagi dalam beberapa kelompok yaitu menurut jenis kelamin, penghasilan, usia, tingkat pendidikan dan

pekerjaan.

Tabel 2 Karakteristik Responden Berdasarkan Jenis Kelamin

\begin{tabular}{|c|l|c|c|}
\hline No & \multicolumn{1}{|c|}{ Jenis Kelamin } & Jumlah & Persentase \\
\hline 1 & Laki-Laki & 39 & $39 \%$ \\
\hline 2 & Perempuan & 61 & $61 \%$ \\
\hline & Total & 100 & $100 \%$ \\
\hline
\end{tabular}

Tabel di atas menunjukkan bahwa dari seluruh responden yang berjumlah 100 orang terdiri dari 39 orang laki-laki atau 39\% dan 61 orang perempuan atau $61 \%$.

Tabel 3 Karakteristik Responden Berdasarkan Penghasilan

\begin{tabular}{|c|l|c|c|}
\hline No & \multicolumn{1}{|c|}{ Penghasilan } & Jumlah & Persentase \\
\hline 1 & Di bawah 1 juta & 37 & $37 \%$ \\
\hline 2 & 1-3 juta & 41 & $41 \%$ \\
\hline 3 & 3-5 juta & 19 & $19 \%$ \\
\hline 4 & 5-7 juta & 2 & $2 \%$ \\
\hline 5 & 7-10 juta & 1 & $1 \%$ \\
\hline 6 & Di atas 10 juta & 0 & $0 \%$ \\
\hline & Total & $\mathbf{1 0 0}$ & $\mathbf{1 0 0 \%}$ \\
\hline
\end{tabular}

Tabel di atas menunjukkan bahwa dari seluruh responden yang berjumlah 100 orang, memiliki penghasilan paling banyak adalah di antara 1-3 juta dengan tingkat persentase sebesar $41 \%$ dan berikutnya penghasilan di bawah 1 juta sebesar $37 \%$, serta penghasilan 3-5 juta sebesar $19 \%$.

Tabel 4 Karakteristik Responden Berdasarkan Usia

\begin{tabular}{|c|l|c|c|}
\hline No & $\begin{array}{c}\text { Rentang Usia } \\
\text { (Tahun) }\end{array}$ & Jumlah & Persentase \\
\hline 1 & $17-25$ & 30 & $30 \%$ \\
\hline 2 & $26-30$ & 22 & $22 \%$ \\
\hline 3 & $31-45$ & 36 & $36 \%$ \\
\hline 4 & Di atas 45 & 12 & $12 \%$ \\
\hline & Total & $\mathbf{1 0 0}$ & $\mathbf{1 0 0 \%}$ \\
\hline
\end{tabular}

Berdasarkan tabel di atas menunjukkan bahwa usia responden yang paling dominan adalah antara usia
31-45 tahun sebanyak 36 orang atau $36 \%$ selanjutnya antara usia 17-25 tahun sebanyak 30 orang atau $30 \%$, 
kemudian disusul usia 26-30 sebanyak 22 orang atau $22 \%$ dan terakhir yang berusia di atas 45 tahun sebanyak 12 orang atau $12 \%$.

Tabel 5 Karakteristik Responden Berdasarkan Tingkat Pendidikan

\begin{tabular}{|c|l|c|c|}
\hline No & \multicolumn{1}{|c|}{ Tingkat Pendidikan } & Jumlah & Persentase \\
\hline 1 & SMU/Sederajat & 40 & $40 \%$ \\
\hline 2 & Diploma & 4 & $4 \%$ \\
\hline 3 & S1 & 46 & $46 \%$ \\
\hline 4 & S2 & 10 & $10 \%$ \\
\hline 5 & S3 & 0 & $0 \%$ \\
\hline & Total & $\mathbf{1 0 0}$ & $\mathbf{1 0 0 \%}$ \\
\hline
\end{tabular}

Tabel di atas menjelaskan bahwa pendidikan terakhir yang terselesaikan oleh responden didominasi oleh tingkat S1 sebanyak 46 orang atau $46 \%$ disusul oleh pendidikan
SMU/Sederajat sebanyak 40 orang atau $40 \%$ dan pendidikan S2 sebanyak 10 orang atau $10 \%$ serta pendidikan Diploma sebanyak 4 orang atau $4 \%$.

Tabel 6 Karakteristik Responden Berdasarkan Pekerjaan

\begin{tabular}{|c|l|c|c|}
\hline No & Jenis Pekerjaan & Jumlah & Persentase \\
\hline 1 & Mahasiswa & 20 & $20 \%$ \\
\hline 2 & PNS/Pegawai Swasta & 24 & $24 \%$ \\
\hline 3 & Pengusaha/Wiraswasta & 21 & $21 \%$ \\
\hline 4 & Professional & 20 & $20 \%$ \\
\hline 5 & Masyarakat umum & 15 & $15 \%$ \\
\hline & Total & $\mathbf{1 0 0}$ & $\mathbf{1 0 0 \%}$ \\
\hline
\end{tabular}

Pada tabel di atas menjelaskan bahwa jenis pekerjaan yang dilakukan oleh responden didominasi oleh PNS (Pegawai Negeri Sipil) / Pegawai swasta yaitu sebanyak 24 orang atau sebanyak $24 \%$ kemudian disusul oleh responden yang bekerja sebagai pengusaha/wiraswasta sebanyak 21 orang atau $21 \%$, kemudian sebagai mahasiswa dan professional masingmasing sebanyak 20 orang atau $20 \%$.
Kemudian yang paling terakhir adalah responden dari masyarakat umum sebanyak 15 orang atau $15 \%$.

\section{Hasil Analisis Data Uji Validitas}

Uji Validitas digunakan untuk mengukur valid atau tidaknya suatu kuesioner. Hasil uiji validitas dapat dilihat dengan tabel sebagai berikut: 
a. Pengetahuan (X1)

\begin{tabular}{|c|c|c|c|}
\hline Item Pertanyaan & $\begin{array}{c}\text { Total Pearson } \\
\text { Correlation }\end{array}$ & $\begin{array}{c}\text { R-TABEL } \\
\text { SAMPEL } \\
(100-1) 99\end{array}$ & Keterangan \\
\hline $\mathrm{X} 1.1$ & $.811^{* *}$ & 0.187904 & VALID \\
\hline $\mathrm{X} 1.2$ & $.716^{* *}$ & 0.187904 & VALID \\
\hline $\mathrm{X} 1.3$ & $.769^{* *}$ & 0.187904 & VALID \\
\hline $\mathrm{X} 1.4$ & $.804^{* *}$ & 0.187904 & VALID \\
\hline $\mathrm{X} 1.5$ & $.772^{* *}$ & 0.187904 & VALID \\
\hline
\end{tabular}

Berdasarkan hasil uji validitas diatas menunjukkan bahwa nilai $r$ hitung setiap instrumen penelitian variabel bebas yaitu pengetahuan (X1) yang diukur, lebih besar dari nilai $r$ standar $=0,3 . \quad(n=100$ dengan tingkat keyakinan $\alpha=5 \%$ ), sehingga dinyatakan valid. Oleh karena itu keseluruhan item pernyataan pada variabel X1 dapat digunakan karena dinyatakan valid.

b. Persepsi (X2)

\begin{tabular}{|c|c|c|c|}
\hline Item Pertanyaan & $\begin{array}{c}\text { Total Pearson } \\
\text { Correlation }\end{array}$ & $\begin{array}{c}\text { R-TABEL } \\
\text { SAMPEL } \\
(100-1) 99\end{array}$ & Keterangan \\
\hline $\mathrm{X} 2.1$ & $.704^{* *}$ & 0.187904 & VALID \\
\hline $\mathrm{X} 2.2$ & $.536^{* *}$ & 0.187904 & VALID \\
\hline $\mathrm{X} 2.3$ & $.444^{* *}$ & 0.187904 & VALID \\
\hline $\mathrm{X} 2.4$ & $.578^{* *}$ & 0.187904 & VALID \\
\hline $\mathrm{X} 2.5$ & $.626^{* *}$ & 0.187904 & VALID \\
\hline
\end{tabular}

Berdasarkan hasil uji validitas diatas menunjukkan bahwa nilai $r$ hitung setiap instrumen penelitian variabel bebas yaitu persepsi (X2) yang diukur, lebih besar dari nilai $r$ standar $=$
0,3. ( $n=100$ dengan tingkat keyakinan $\alpha$ $=5 \%)$, sehingga dinyatakan valid. Oleh karena itu keseluruhan item pernyataan pada variabel $\mathrm{X} 2$ dapat digunakan karena dinyatakan valid.

\section{c. Preferensi risiko (X3)}

\begin{tabular}{|c|c|c|c|}
\hline Item Pertanyaan & $\begin{array}{c}\text { Total Pearson } \\
\text { Correlation }\end{array}$ & $\begin{array}{c}\text { R-TABEL } \\
\text { SAMPEL } \\
(100-1) 99\end{array}$ & Keterangan \\
\hline X3.1 & $.642^{* *}$ & 0.187904 & VALID \\
\hline X3.2 & $.725^{* *}$ & 0.187904 & VALID \\
\hline X3.3 & $.681^{* *}$ & 0.187904 & VALID \\
\hline X3.4 & $.686^{* *}$ & 0.187904 & VALID \\
\hline X3.5 & $.663^{* *}$ & 0.187904 & VALID \\
\hline
\end{tabular}


Berdasarkan hasil uji validitas diatas menunjukkan bahwa nilai $r$ hitung setiap instrumen penelitian variabel bebas yaitu preferensi risiko (X3) yang diukur, lebih besar dari nilai $r$ standar $=0,3 . \quad(n=100$ dengan tingkat keyakinan $\alpha=5 \%$ ), sehingga dinyatakan valid. Oleh karena itu keseluruhan item pernyataan pada variabel X3 dapat digunakan karena dinyatakan valid.

d. Minat Investasi ( $Y$ )

\begin{tabular}{|c|c|c|c|}
\hline Item Pertanyaan & $\begin{array}{c}\text { Total Pearson } \\
\text { Correlation }\end{array}$ & $\begin{array}{c}\text { R-TABEL } \\
\text { SAMPEL } \\
(100-1) 99\end{array}$ & Keterangan \\
\hline Y.1 & $.774^{* *}$ & 0.187904 & VALID \\
\hline Y.2 & $.770^{* *}$ & 0.187904 & VALID \\
\hline Y.3 & $.756^{* *}$ & 0.187904 & VALID \\
\hline Y.4 & $.767^{* *}$ & 0.187904 & VALID \\
\hline Y.5 & $.662^{* *}$ & 0.187904 & VALID \\
\hline
\end{tabular}

Berdasarkan hasil uji validitas diatas menunjukkan bahwa nilai $r$ hitung setiap instrumen penelitian variabel terikat yaitu Minat ( $Y$ ) yang diukur, lebih besar dari nilai $r$ standar $=0,3$. ( $n=100$ dengan tingkat keyakinan $\alpha=$ $5 \%)$, sehingga dinyatakan valid. Oleh karena itu keseluruhan item pernyataan pada variabel $Y$ dapat digunakan karena dinyatakan valid.

\section{Uji Reliabilitas}

Uji reliabilitas digunakan untuk mengukur suatu kuesioner, suatu kuisioner dikatakan reliabel atau handal jika jawaban seseorang terhadap pernyataan adalah konsisten atau stabil dari waktu ke waktu. Hasil pengujian Uji Reliabilitas dapat dilihat dengan tabel sebagai berikut:

\section{a. Pengetahuan (X1)}

Reliability Statistics

\begin{tabular}{|r|r|}
\hline Cronbach's Alpha & N of Items \\
\hline .833 & 5 \\
\hline
\end{tabular}

Dari tabel tersebut diatas terlihat bahwa nilai reliabilitas variabel
$0,833>0,60$ sehingga hasil ini menunjukkan bahwa butir pertanyaan pada variabel tersebut handal untuk mengukur variabelnya masing-masing. Hasil uji reliabilitas diperoleh variabel pengetahuan realiabel sehingga dapat dilanjutkan ke uji regresi linear berganda.

\section{b. Persepsi (X2)}

Reliability Statistics

\begin{tabular}{|r|r|}
\hline Cronbach's Alpha & N of Items \\
\hline .611 & 5 \\
\hline
\end{tabular}

Dari tabel tersebut diatas terlihat bahwa nilai reliabilitas variabel $0,611>0,60$ sehingga hasil ini menunjukkan bahwa butir pertanyaan pada variabel tersebut handal untuk mengukur variabelnya masing-masing. Hasil uji reliabilitas diperoleh variabel persepsi realiabel sehingga dapat dilanjutkan ke uji regresi linear berganda. 
c. Preferensi risiko (X3)

Reliability Statistics

\begin{tabular}{|r|r|}
\hline Cronbach's Alpha & N of Items \\
\hline .704 & 5 \\
\hline
\end{tabular}

Dari tabel tersebut diatas terlihat bahwa nilai reliabilitas variabel $0,704>0,60$ sehingga hasil ini menunjukkan bahwa butir pertanyaan pada variabel tersebut handal untuk mengukur variabelnya masing-masing. Hasil uji reliabilitas diperoleh variabel preferensi risiko realiabel sehingga dapat dilanjutkan ke uji regresi linear berganda.

\section{d. Minat Investasi ( $Y$ )}

Reliability Statistics

\begin{tabular}{|r|r|}
\hline Cronbach's Alpha & N of Items \\
\hline .791 & 5 \\
\hline
\end{tabular}

Dari tabel tersebut diatas terlihat bahwa nilai reliabilitas variabel $0,791>0,60$ sehingga hasil ini menunjukkan bahwa butir pertanyaan pada variabel tersebut handal untuk mengukur variabelnya masing-masing. Hasil uji reliabilitas diperoleh variabel minat investasi realiabel sehingga dapat dilanjutkan ke uji regresi linear berganda.

\section{Pengujian Hipotesis \\ Koefisien Determinasi}

Koefisien determinasi adalah nilai yang menunjukkan proporsi pengaruh variable indepneden yang dapat menjelaskan variable dependen. Hasil pengujian SPSS didapatkan nilai koefisien sebagai berikut:

Tabel 7 Koefisien Determinasi

\begin{tabular}{|l|r|r|r|r|}
\hline Model & $\mathrm{R}$ & R Square & $\begin{array}{c}\text { Adjusted R } \\
\text { Square }\end{array}$ & $\begin{array}{c}\text { Std. Error of } \\
\text { the Estimate }\end{array}$ \\
\hline 1 & $.789^{\mathrm{a}}$ & .623 & .611 & 2.15265 \\
\hline
\end{tabular}

a. Predictors: (Constant), X3, X2, X1

Dari tabel di atas dapat diketahui bahwa $R^{2}$ sebvesar 0,623, nilai ini menunjukkan bahwa variable independen (pengetahuan, persepsi dan preferensi risiko) mampu menjelaskan variable dependen (minat masyarakat berinvestasi di pasar modal) sebesar $62,3 \%$ dan sisanya sebesar $37,7 \%$ dijelaskan oleh variabel lain yang tidak diteliti dalam penelitian ini. 


\section{Analisis Regresi Linier Berganda}

Analisis regresi linier ini digunakan untuk mengetahui besarnya pengaruh variabel bebas terhadap variabel terikat. Berdasarkan perhitungan melalui komputer dengan menggunakan program SPSS diperoleh hasil regresi sebagai berikut:

Tabel 8 Hasil Uji Parsial

\begin{tabular}{|c|c|c|c|c|c|c|}
\hline \multirow{2}{*}{\multicolumn{2}{|c|}{ Model }} & \multicolumn{2}{|c|}{ Unstandardized Coefficients } & $\begin{array}{l}\text { Standardized } \\
\text { Coefficients }\end{array}$ & \multirow[b]{2}{*}{$\mathrm{t}$} & \multirow[b]{2}{*}{ Sig. } \\
\hline & & B & Std. Error & Beta & & \\
\hline \multirow[t]{4}{*}{1} & (Constant) & 1.759 & 1.363 & & 1.291 & 200 \\
\hline & $\mathrm{X} 1$ & .336 & .066 & 390 & 5.105 & .000 \\
\hline & $\mathrm{X} 2$ & .032 & .083 & .029 & .386 & 700 \\
\hline & X3 & .511 & .093 & .483 & 5.492 & .000 \\
\hline
\end{tabular}

a. Dependent Variable: $Y$

Berdasarkan tabel 8 di atas maka dapat ditentukan persamaan regresinya sebagai berikut:

$$
Y=1,759+0,336 X 1+
$$

$0,032 \times 2+0,511 \times 3$

Dimana :

$\mathrm{Y}=$ Minat masyarakat berinvestasi

di pasar modal

$\mathrm{X} 1$ = Pengetahuan

$\mathrm{X} 2=$ Persepsi

X3 = Preferensi risiko

\section{Uji Parsial}

Pengujian secara parsial untuk mengetahui apakah ada pengaruh antara masing-masing variabel $\mathrm{X} 1, \mathrm{X} 2$, dan $X 3$ terhadap minat masyarakat untuk berinvestasi di pasar modal. Berdasarkan hasil perhitungan SPSS sebagaimana dapat di lihat pada Tabel 8 diperoleh hasil sebagai berikut:

- Nilai signifikansi untuk variabel X1 (pengetahuan) sebesar 0,000, yang menunjukkan bahwa nilai signifikansi sebesar 0,000 < 0.05, maka dapat disimpulkan bahwa pengetahuan berpengaruh terhadap minat masyarakat untuk berinvestasi di pasar modal.

- Nilai signifikansi untuk variabel X2 (persepsi) sebesar 0,700 , yang menunjukkan bahwa nilai signifikansi sebesar 0,000 > 0.05), maka dapat disimpulkan bahwa persepsi tidak berpengaruh terhadap minat masyarakat untuk berinvestasi di pasar modal.

- Nilai signifikansi untuk variabel X3 (preferensi risiko) sebesar 0,000 , yang menunjukkan bahwa nilai signifikansi sebesar 0,000< 0.05, maka dapat disimpulkan bahwa preferensi risiko berpengaruh terhadap minat masyarakat untuk berinvestasi di pasar modal. 


\section{Uji Simultan}

Tabel 9 Uji Simultan

\begin{tabular}{|c|c|c|c|c|c|c|}
\hline & & $\begin{array}{l}\text { Sum of } \\
\text { Squares }\end{array}$ & Df & Mean Square & $\mathrm{F}$ & Sig. \\
\hline \multirow[t]{3}{*}{1} & Regression & 734.145 & 3 & \multirow{3}{*}{$\begin{array}{r}244.715 \\
4.634\end{array}$} & \multirow[t]{3}{*}{52.810} & \multirow[t]{3}{*}{$.000^{b}$} \\
\hline & Residual & 444.855 & 96 & & & \\
\hline & Total & 1179.000 & 99 & & & \\
\hline
\end{tabular}

a. Dependent Variable: $Y$

b. Predictors: (Constant), X3, X2, X1

Pengujian secara simultan dilakukan untuk mengetahui apakah ada pengaruh antara variabel $\mathrm{X} 1, \mathrm{X} 2$, dan $\mathrm{X} 3$ secara bersama-sama terhadap variabel Y. Berdasarkan hasil perhitungan SPSS sebagaimana dapat di lihat pada Tabel 9 diperoleh nilai signifikansi 0,000. Ketentuan pengambilan keputusan hipotesis diterima atau ditolak didasarkan pada besarnya nilai signifikansi. Jika signifikansi lebih kecil atau sama dengan $0.05(<0.05)$, maka hipotesis kerja diterima dan sebaliknya. Hasil penelitian diperoleh nilai signifikansi sebesar 0,000 (< 0.05), maka dapat disimpulkan bahwa secara simultan bersama-sama, pengetahuan, persepsi dan preferensi risiko berpengaruh terhadap minat masyarakat untuk berinvestasi di pasar modal.

\section{Pembahasan}

Tingkat literasi keuangan masyarakat di wilayah Indonesia Timur khususnya di Sulawesi Barat masih cukup rendah (wawancara dengan Kepala Perwakilan Bursa Efek Makassar). Tingkat literasi keuangan yang dimaksud dalam kaitannya dengan keinginan dan perilaku investasi masyarakat. Konsumsi yang tinggi oleh masyarakat belum diikuti dengan pola investasi, kalaupun masyarakat berinvestasi umumnya hanya pada aset riil seperti, membeli tanah, bangunan, dan membuka usaha. Di sisi lain, inevstasi pada aset-aset keuangan masih sangat kurang termasuk juga investasi pada aset keuangan yang diperdagangkan di pasar modal. Pihak Bursa Efek Makassar telah melakukan beberapa upaya di antaranya melakukan edukasi ke kampus dan ke masyarakat melalui program "Yuk Nabung Saham" untuk mengedukasi dan mensosialisasikan produk saham sebagai instrumen investasi yang dapat dipilih masyarakat selain berinvestasi di aset riil.

Berdasarkan hasil analisis dari kuisioner yang diperoleh dari 100 responden menunjukkan bahwa sebagian besar responden secara umum telah mengetahui tentang investasi sahamn dan pasar modal. Akan tetapi hanya sebagian kecil yang kemudian telah melakukan investasi di pasar modal tersebut. Dari sisi persepsi masyarakat, pada umumnya masih banyak persepsi yang tidak tepat terkait pasar modal dan investasi saham yang berkembang di masyarakat, seperti stigma negatif tentang investasi saham yang dipersamakan dengan berjudi. Dari sisi preferensi risiko, seabagian besar masyarakat di kabupaten Majene 
tergolong kategori investor yang risk averse atau menghindari risiko.

Berdasarkan hasil analisis regresi linier berganda, diperoleh hasil yaitu, secara bersama-sama, ketiga variabel: pengetahuan, persepsi dan preferensi risiko berpengaruh terhadap minat masyarakat untuk berinvestasi di pasar modal. Akan tetapi secara parsial, hanya variabel pengetahuan dan preferensi risiko yang mempengaruhi minat masyarakat untuk berinvestasi di pasar modal. Hal ini menunjukkan bahwa stigma negatif terkait persepsi masyarakat akan investasi saham tidak mempengaruhi minat masyarakat dalam berinvestasi. Akan tetapi tingkat pengetahuan dan preferensi risiko lah yang lebih mempengaruhi. Hal ini juga secara tidak langsung menunjukkan bahwa masyarakat masih sangat kekurangan informasi yang luas dan mendalam tentang investasi di pasar modal. Begitu juga pemahaman masyarakat akan risiko dalam berinvestasi.

\section{KESIMPULAN DAN SARAN \\ Kesimpulan}

Beradasarkan hasil analisis regresi linier berganda diperoleh kesimpulan sebagai berikut:

1. Pengetahuan tentang pasar modal berpengaruh terhadap minat masyarakat di Kabupaten Majene untuk berinvestasi di pasar modal.

2. Persepsi tentang pasar modal tidak berpengaruh terhadap minat masyarakat di Kabupaten Majene untuk berinvestasi di pasar modal.

3. Preferensi risiko berpengaruh terhadap minat masyarakat di
Kabupaten Majene untuk berinvestasi di pasar modal.

4. Secara bersama-sama, pengetahuan, persepsi dan preferensi risiko berpengaruh terhadap minat masyarakat di Kabupaten Majene untuk berinvestasi di pasar modal.

\section{Saran}

Berdasarkan hasil kesimpulan di atas maka secara umum peneliti dapat memberikan saran khususnya kepada pemerintah dalam hal ini Otoritas Jasa Keuangan dan PT. Bursa Efek Indonesia sebagai regulator di industri pasar modal, untuk dapat meningkatkan sosialisasi kepada masyarakat agar masyarakat lebih mengenal dan memahami tentang investasi di pasar modal.

\section{DAFTAR PUSTAKA}

Aiken, L.R. 1994. Psychologycal Testing and Assement. MA: Allyn and Bacon. P.

Alleyne, Philmore and Broom, Tracey.2011."Using The Theory of Planned Behaviour and Rsik Prospensity to Measurelnvestment Intention among Future Investors".Journal of Eastern Carribean Studies, Vol.36,No.1,1-20.

Anton M. Moeliono dkk, Kamus Besar Bahasa Indonesia, Jakarta: Balai Pustaka, 1999.

Ary Permatadeny, Nevita dan Arifin, Zainal. 2015.

Perilaku,Karakteristik,Persepsi

Masyarakat Terhadap Bank Syariah di Eks Karasidenan Kediri. Jurnal Nusantara of Research. 2:151. 
Darmadji,Tjiptono, dan Fakhruddin. 2012. Pasar Modal di Indonesia. Salemba Empat. Jakarta.

Fahmi,Yofi.L.Hadi. 2009. Teori Portofolio dan Analisis Investasi. Cetakan Pertama. Alfabeta. Bandung.

Huda,Nurul dan Nasution,Mustafa Edwin. 2008. Investasi Pada Pasar Modal Syariah.Kencana.Jakarta.

Husnan, Suad. 2009. Dasar-Dasar Teori Portofolio \& Analisis Sekuritas. UPP STIM YKPN. Yogyakarta.

Ikatan Akuntan Indonesia. 2008. Standar Akuntansi Keuangan. Salemba Empat. Jakarta.

Kasmir dan Jakfar. 2012. Studi Kelayakan Bisnis. Kencana. Jakarta.

Meidar F.M. 1997. Kamus Lengkap Exclusive Inggris - Indonesia. Eskamedia. Jakarta.

Philip Kotler, Kevin Lane keller,2009.Manajemen Pemasaran. Erlangga. Jakarta.

Salim, P., Yeny Salim. 1996. Kamus Bahasa Indonesia Kontemporer, Edisi I. Modern English PressJakarta.

Stiggins, R.J. 1994. Student-Centered Classroom Assesment. New
York: Merruean Imprint of Macmillan College publishing Co.

Sugiyono. 2008. Metode Penelitian Kuantitatif Kualitatif dan $R \& D$. Alfabeta. Bandung.

Sutisna. 2010. Perilaku Konsumen dan Komunikasi Pemasaran. PT Remaja Rosdakarya. Bandung.

Ujang Sumarwan, Perilaku Konsumen T eori dan Penerapannya dalam $P$ emasaran,Jakarta: Ghalia Indon esia, 2003, hlm. 120-123

Undang-Undang Republik Indonesia Nomor 8 Tahun 1995 tentang Pasar Modal. Kementrian Hukum dan HAM Republik Indonesia. Jakarta.

http://www.ac.id-Preferensi-

Konsumen diakses tanggal 25 Maret 2017

https://majenekab.bps.go.id diakses tanggal 25 Februari 2017

Http://www.ac.id-PreferensiKonsumen

www.epaper.bisnis.com diakses tanggal 20 Februari 2017

www.ksei.co.id, diakses maret 2017

www.ojk.go.id diakses tanggal 22 Februari 2017

http://kbbi.web.id 